\title{
波浪推算に基づく佐渡島の波浪遮蔽効果の検討
}

\section{A CONSIDERATION OF SHELTERING EFFECTS OF SADO ISLAND ON OCEAN WAVES OFF HOKURIKU COAST BASED ON WAVE HINDCASTING}

\author{
山口正隆*・畑田佳男**.日野幹雄*** \\ By Masataka YAMAGUCHI, Yoshio HATADA and Mikio HINO
}

\begin{abstract}
A numerical wave prediction model based on the radiative transfer equation is applied to the estimation of the sheltering effects of Sado Island on ocean waves off the Hokuriku Coast. The model is operated in two steps. First, ocean waves in the Japan Sea are computed on a coarse mesh during a period of severe seasonal wind. The wind distribution is given from a weather map analysis based on the spline function approximation to isobars. Next, ocean waves off the Hokuriku Coast are hindcasted on a fine mesh by giving the computed results on a coarse mesh as the inflow boundary condition on the open boundary. The computations show a satisfactory agreement with the observations along the Japanese coast. The sheltering effect of Sado Island is estimated from a comparison with the computation neglecting the island.
\end{abstract}

\section{1. 緒言}

冬期季節風時の日本海沿岸では長時間連吹する強風に より発達した異常波浪がしばしば来襲し, 各地で海岸や 堤防の欠壊など海岸波浪災害が頻発するのは周知の事実 であるが，日本海沿岸のうち，酒田，新潟から富山にか けての北陸沿岸では, 佐渡島および能登半島の存在に よって外海で発達した波浪が遮蔽される地域が存在する ので，そこでは波浪災害も軽滅されると考えられる.

さて, 佐渡島の波浪遮蔽効果を最初に定量的に研究し

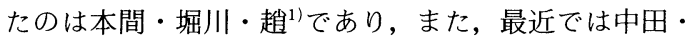
及川・中尾・高橋・榎原 ${ }^{2}$ が同梯の研究を行っている. 彼らはそれぞれ佐渡島の入川と新潟西海岸および新潟東 港，佐渡島の弾崎と新潟東港および西港で取得された風 および波浪観測資料の詳細な解析から, 新潟海岸に及ぼ す佐渡島の波浪遮蔽効果を実証するとともに，佐渡島の 遮蔽効果が少なくとも定性的には方向分散の観点から説 明されることを明らかにした．特に，中田らは，周波数 スペクトルが佐渡島の遮蔽効果および局所風の影響によ

* 正会員 工博 愛媛大学教授 工学部海洋工学科 ( ₹ 790 松山市文京町 3 番)

** 正会員 工修 愛媛大学助手 工学部海洋工学科 (同上)

*** 学生会員 愛媛大学大学院 工学研究科 (同上)
りどのように変化するかを示す興味深い資料を提示し， こうした変化を再現するには，方向分散のほか局所風に 伴う波浪を考慮する必要があることを明らかにした。し かしながら，これらの研究は新潟東港あるいは西港とい うごく局所的に限られた地点に及ぼす佐渡島の遮蔽効果 を検討したものであり，佐渡島の遮蔽効果を平面的に明 らかにしたものではない.したがって，こうした点を究 明するためには，北陸海岸に沿う広域的な波浪観測結果 の解析を行うとともに，佐渡島を含む日本海全域を対象 として実施した波浪推算結果の考察に基づいて検討を進 める必要がある.

ところで，著者ら゙`はこれまでエネルギー平衡方程式 に基づく波浪推算モデルを開発し，琵琶湖，大阪湾およ び伊予灘においてその適用性を検討してきた。また，ひ きつづき，砕波項の表示法や数值計算法などに関して従 来の波浪推算法に大幅な改良を加えた波浪推算モデル4) と, 等圧線のスプライン関数近似に基づく海上風推定 法5)新たに開発した．そしてこれらのモデルに基づき， 昭和 55 年 12 月季節風時における佐渡島の遮蔽効果を検 討し ${ }^{6)}$, 遮蔽効果の影響領域が外海から侵入する波浪の 入射方向によって変化すること,および計算結果は観測 結果と比較的一致することを明らかにした。しかしなが ら, 対象とした季節風時には $\mathrm{N}$ 方向の風が卓越したた 
め, 佐渡島の入射波向に対する投影長が小さく，佐渡島 の遮蔽効果があまり有効に働かなかったし，計算対象と した季節風もそれほど規模の大きいものではなかった.

そこで，本研究は前述の研究に引き続き，波浪追算に 基づき，北陸海岸一帯に及ぼす佐渡島の遮蔽効果を広域 的に究明しようとするものである. そのため，過去数十 年間のうちで日本海沿岸に最大級の波浪を発生させ，甚 大な海岸波浪災害をもたらした昭和 45 年 1 月 30 日〜2 月 3 日にかけての季節風時を研究対象に取り上げ，入射 波向に対し佐渡島の投影長が大きい NW 方向の強風が 吹送したこの季節風時に対する波浪追算を行う。すなわ ち, 第 1 段階では等圧線のスプライン関数近似に基づく 方法によって推定した海上風を日本海全体の大領域に入 力して波浪追算を行い，日本海沿岸の波浪観測結果との 比較から外海における波浪推算モデルの適用性を検討す る. 第 2 段階では, 能登半島之秋田を結ぶ境界線以南の 小領域を計算対象領域とし，その境界線上で外海での計 算結果を入力するとともに，前述の海上風を吹送させた 波浪追算を行い, 北陸海岸での波浪観測結果と比較・検 討する．また，小領域での波浪追算は佐渡島の存在を無 視した場合についても実施し，両者の計算結果の比較か ら北陸海岸に沿う波高分布に及ぼす佐渡島の影響を考察 する，なお，単純な風条件のもとでの佐渡島の遮蔽効果 を明らかにするため，日本海全体で $\mathrm{N}$ および $\mathrm{NW}$ 方向 をもつ一様風が長時間吹送した場合の計算も同様の方法 により実施する.

\section{2. 波浪推算モデルの概要}

波浪推算モデルに用いられるエネルギー平衡方程式 は,

$$
\frac{\partial E(f, \theta)}{\partial t}+c_{g} \cos \theta \frac{\partial E(f, \theta)}{\partial x}+c_{g} \sin \theta \frac{\partial E(f, \theta)}{\partial y}=G
$$

で表わされる.ここに, $f$ : 周知数, $\theta$ : 方位角, $c_{g}$ : 群速度, $E(f, \theta)$ : 方向スペクトル，および $G:$ エネル ギーの流出入を表わす source function，である.

さて，新しいモデルでは，まず波浪の発生項のかわり に，実用上無視し得る風速 $2 \mathrm{~m} / \mathrm{s}$ に対するPiersonMoskowitz スペクトルおよび $\cos ^{4} \theta$ 型方向分布関数か ら計算される方向スペクトルの初期値を与えるととも に，発達項として，低周波側で cut-off 周波数をもち， 発達率が 0 となる Barnett ${ }^{7)}$ による表示式を採用する. また，非線形干渉項の表示式として用いられた Barnett ${ }^{7}$ のパラメーター表示式による計算結果と厳密な数值積分 結果を比較すると，前者は $\gamma>1$ をもつ周波数スペクト ルのエネルギー流入域に対して粗い近似で $1 / \gamma$ 程度の 值を与えるので, 非線形干渉項が流入項として作用する
場合には Barnett の表示式を $\gamma$ 倍して用いることにす る.ここに， $\gamma$ はJONSWAP スペクトルの尖鋭度を表 わすスペクトル形状パラメーターである，さらに，砕波 によるエネルギー逸散は Resio and Vincent ${ }^{8}$ にならい, 砕波によってもその方向分布関数は不変であると仮定 し, $E_{\text {old }}(f)>E_{\infty}(f)$ の場合, 平衡周波数スペクトルを 用いた次式によって表現する。

$$
E_{\text {new }}(f, \theta)=E_{\text {old }}(f, \theta)\left\{E_{\infty}(f) / E_{\text {old }}(f)\right\}
$$

ここに, $E(f)$ : 周波数スペクトル，および $E_{\infty}(f)$ : 平衡 周波数スペクトル，であり， suffix の 'old'亡 'new' は それぞれ砕波前と砕波後を示す。なお，逆風による減衰 項の評価は磯崎・宇治 ${ }^{9}$ 之同様に, 全周波数について有 限值をとる井上による Miles 機構の表示式を便宜的に 代用して行った.

次に, 式（1）の数值積分は，1タイムステップ $\Delta t$ 内で式( 1 )の右辺を 0 とした移流・伝播方程式と移流・ 伝播項を 0 とした発達・減衰方程式を交互に解く時間分 割法によることとし，ここでは，前者の数值積分に対し 特性曲線法の一種である piecewise ray method を, 一 方後者に対して解析解を使用する．すなわち，各成分波 が $\Delta t$ 後に計算格子点に到達する波浪の伝播経路を考 え，まず出発点の方向スペクトル值を周囲の計算格子点 の方向スペクトル值から 3 次 Lagrange 補間式を用いて 内挿したのち，この内挿結果を初期値として発達・減衰 方程式の解析解から $\Delta t$ 後の解を求めた. ついで, 各方 向に関する計算の終了後，砕波の影響を式 $(2)$ に従つ て考慮し， $\Delta t$ 後の最終的な解とした。そしてこの計算 過程を繰り返すことにより方向スペクトルの時空間変化 を計算した。

\section{3. 日本海における波浪追算}

\section{（1）計算方法}

波浪追算に用いた計算格子網は，Fig. 1 に示すように 日本海全体を格子間隔 $\Delta s=40 \mathrm{~km}$ で $26 \times 44$ に分割し たもの (大領域) であり，周囲の境界はすべて陸地と仮 定している. 計算に用いた周波数は $f=0.05 \sim 0.7 \mathrm{~Hz}$

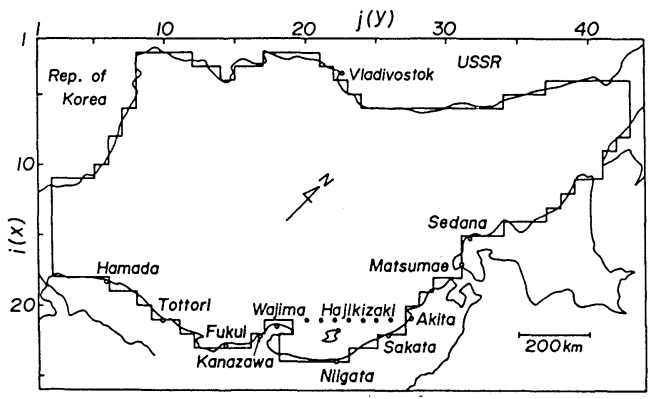

Fig. 1 Grid system (coarse mesh). 
間の 20 個，方向は $\theta=0^{\circ} \sim 360^{\circ}$ を $\Delta \theta=20^{\circ}$ ごとに分割 した 19 個および計算時間間隔は $\Delta t=30 \mathrm{~min}$ である. そして, 周囲の陸上境界での方向スペクトルは 0 という 境界条件のもとに, 式（1）から方向スペクトルの時空 間変化を計算した。

ところで, 本研究の数值モデルでは，砕波項の評価を 式（2）の表示式によっており，この場合の平衡周波数 スペクトルはJONSWAP スペクトル,

$$
\begin{aligned}
& E_{\infty}(f)=\alpha g^{2}(2 \pi)^{-4} f^{-5} \exp \left\{-\frac{5}{4}\left(\frac{f}{f_{p}}\right)^{-4}\right\} \\
& \gamma^{\exp \left\{-\frac{(f-f p)^{2}}{2 \sigma^{2} a b f^{2} p} \mid\right.}
\end{aligned}
$$

で表わされるものとする.ここに， $g$ : 重力の加速度, $f_{p}$ : ピーク周波数, $\sigma_{a b}$ : スペクトル形状パラメーター, である. 式 (3) のパラメーター, $\alpha, \nu\left(=U_{10} f_{p} / g\right)$

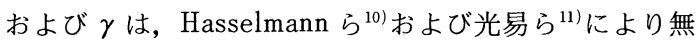
次元吹送距離 $\tilde{F}\left(=g F / U_{\mathrm{i0}}^{2}\right)$ の関数として表わされて いるが, 本研究の発達過程における計算では, 無次元全 エネルギー $\tilde{\varepsilon}\left(=g^{2} \varepsilon / U_{10}^{4}\right)$ と無次元吹送距離の関係から 無次元全エネルギーとの関係に変換した $\alpha, \nu$ およ゙ $\gamma$ を使用した．ここに， $U_{10}$ : 海面上 $10 \mathrm{~m}$ 高度での風速， $F$ : 吹送距離, および $\varepsilon$ : 全エネルギ一，である.なお, 数值モデルにおける平衡スペクトルの実際的な使用法は 複雑であるため簡単に述べることはできないけれども, 大部分の計算では, $f<f_{\rho}$ の周波数範囲における平衡ス ペクトルとして, 指数関数部を $\exp \{-1.25\}$ とした式( 3 ) を用いている.

前述のように，計算格子網の間隔は $\Delta s=40 \mathrm{~km}$ で あって, 最も陸地に近い格子点でも通常の海洋では深海 であるのに対し，波高計設置水深は $50 \mathrm{~m}$ 以浅であって 浅海に相当するので, 高波浪時には砕波や底面摩擦など 水深の影響を受けて波高は深海に比べて減少する.した がって, 観測結果と計算結果との適切な比較を行うため には浅海性の影響を考慮した波浪の数值計算 ${ }^{12)}$ を行う必 要があるが，数十 $\mathrm{km}$ という格子間隔を用いた場合には たとえ浅海波浪の計算を行っても岸から数 $\mathrm{km}$ 離れた波 高計設置点での波浪を評価することができない.そこで, 本研究では波高計設置点に相当する格子点のみ実際の水 深を与えるとともに，次式で表わされる浅海平衡周波数 スペクトルを式（2）に適用することにより便宜的に浅 海性の影響を考慮する方法も採用した.

$$
\begin{aligned}
& E_{\infty}(f)= \alpha \eta\left(H_{1 / 3} / h\right) g^{2}(2 \pi)^{-4} f^{-5} \exp \left\{-\frac{5}{4}\left(\frac{f}{f_{\rho}}\right)^{-4}\right\} \\
& \gamma^{\exp \left\{-\frac{(f-f \rho)^{2}}{2 \sigma^{2} a b b^{2} p} \mid \Phi\left(\omega_{h}\right)\right.} \\
& \Phi\left(\omega_{h}\right)= x^{-2}\left(1+2 \omega_{h}^{2} x / \sinh 2 \omega_{h}^{2} x\right)^{-1} \\
& \eta\left(H_{1 / 3} / h\right)=\max \left\{1-0.582\left(H_{1 / 3} / h\right)+3.54\left(H_{1 / 3} / h\right)^{2}, 1\right\}
\end{aligned}
$$

ここに, $H_{1 / 3}$ : 有義波高, $h$ : 水深, $\omega_{h}^{2}=\sigma^{2} h / g, \sigma$ :角
振動数, $\varkappa=g k / \sigma^{2}$ および $k$ : 波数, である. 式 (4) は Kitaigorodskii らの高周波側に対する平衡スペクト ルとピーク周波数付近に対する JONSWAP スペクトル を組み合わせた TMA スペクトル ${ }^{13)} に$ 平衡定数が相対波 高によっても変化するという琵琶湖における波浪観测資 料の解析から得られた結果 ${ }^{14)}$ を $\eta$ 項として付加したもの である。

\section{（2）海上風の推定法}

波浪追算に先立ち，まず海上風を与えなければならな いが，ここでは前述した等圧線のスプライン関数近似に 基づく天気図解析法による結果を用いる. すなわち，こ の方法は，天気図から読み取った等圧線をスプライン関 数近似して等圧線の曲率半径および接線角を推定すると ともに，気圧傾度も同様にスプライン関数近似して格子 点での傾度風を求めたのち, 適当な補正係数を乗じて海 上風に変換するものであり, 気象学的知識に精通してい なくてもある程度の精度をもつ海上風を比較的簡単に推 定することができる.

本研究で取り上げた対象期間は昭和 45 年 1 月 30 日か ら 2 月 3 日までの 5 日間であり, 推定に際し 3 時間ごと の極東天気図を使用した．この季節風の原因となった低 気圧は, 東シナ海で発生したのち, 太平洋から北上して 日本列島を縦断し，最盛時には中心気圧 $960 \mathrm{mb}$ にも発
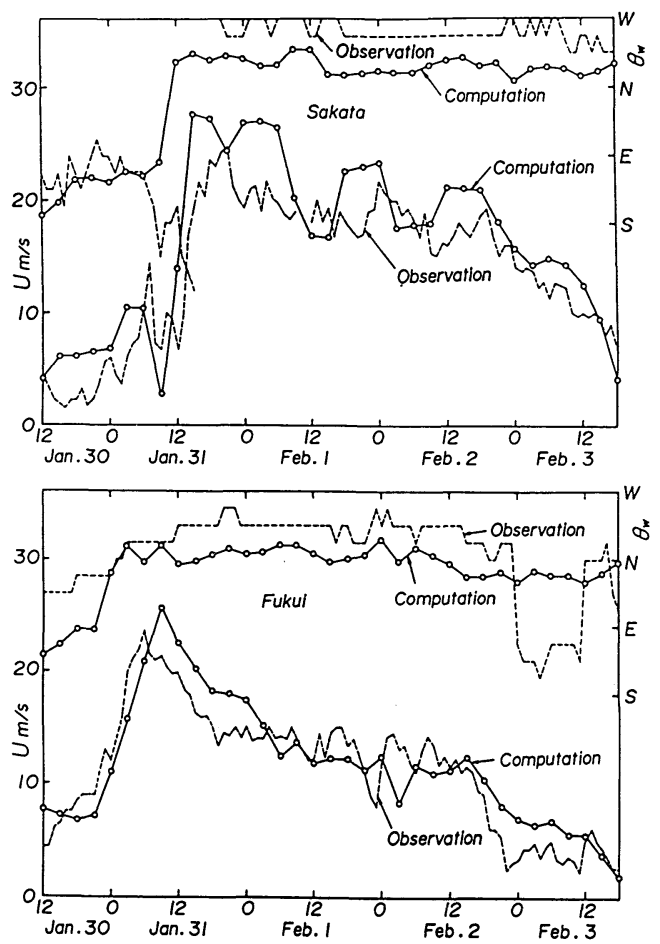

Fig. 2 Comparison between the computed wind and the observed one. 

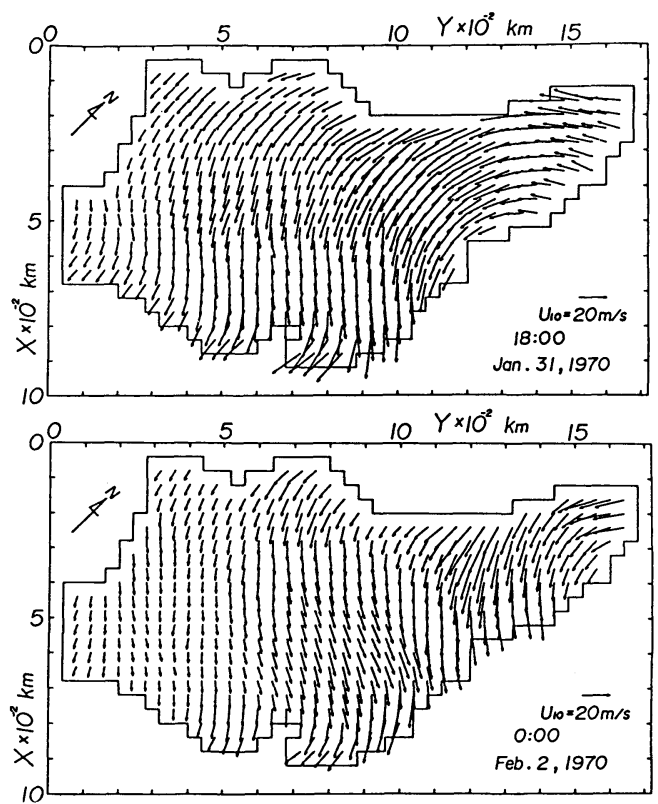

Fig. 3 Spatial distribution of wind vector over the Japan Sea.

達したいわゆる台湾坊主である. Fig. 2 は海上風の推定 結果と観測結果の比較を酒田および福井について示した ものであり，いずれの地点においても計算風向は観測風 向に対して $\mathrm{E}$ 寄りになっているものの，風速の対応は 比較的良好である。 また，他地点での比較においても計 算風向が同様な傾向を示すとともに，計算風速は観測風 速より大きい場合が多かった．しかしながら，観測結果 が陸上風であることを考慮すれば，海上風はスプライン 関数近似に基づく天気図解析法によりある程度の精度を もって推定されたものと考えられる. 一方，Fig. 3 は低 気圧が最盛期を迎え始めた 1 月 31 日 18 時および減衰期 の 2 月 2 日 0 時について大領域波浪計算格子網上に内挿 された海上風の平面分布を示したものである． 31 日 18 時から 2 日 0 時の間に低気圧中心が津軽海峡付近から国 後島付近に移動するのに伴って, 強風域も北東へ移り, 風向もおおむね反時計方向に変化する. そして，31日 18 時には日本海の大部分で $20 \mathrm{~m} / \mathrm{s}$ を越える $\mathrm{NE} \sim \mathrm{NW}$ の風が吹送しているのに対して，2日0時には日本海中 部以西の海域で $10 \mathrm{~m} / \mathrm{s}$ 程度の風速になり，低気圧中心 から離れた海域から風速が低下している．結局これらの 図から，この季節風時には低気圧中心付近を除く海域で おおむね風向 NWをもつ強風が卓越したことがわかる.

(3) 追算結果および考察

Fig. 4 は日本海沿岸に設置されている波高計記録と 2 種類の計算結果 (それぞれ深海平衡周波数スペクトルお よび浅海平衡周波数スペクトルを用いた場合）との比較

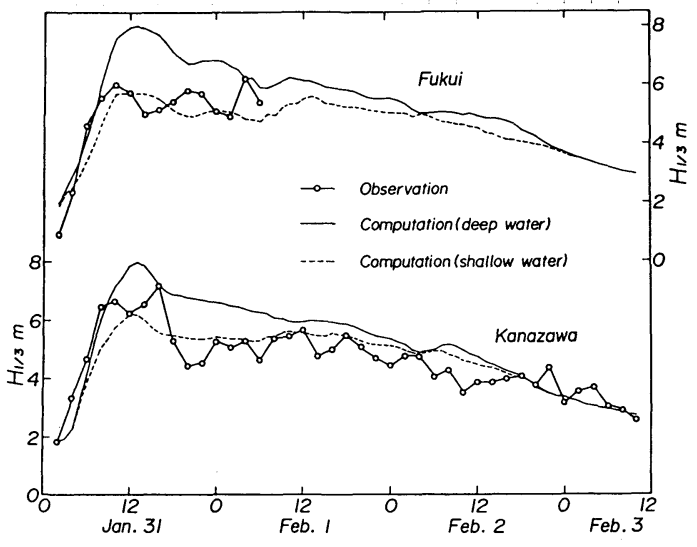

Fig. 4 Comparison between the computed significant wave height and the observed one (1).
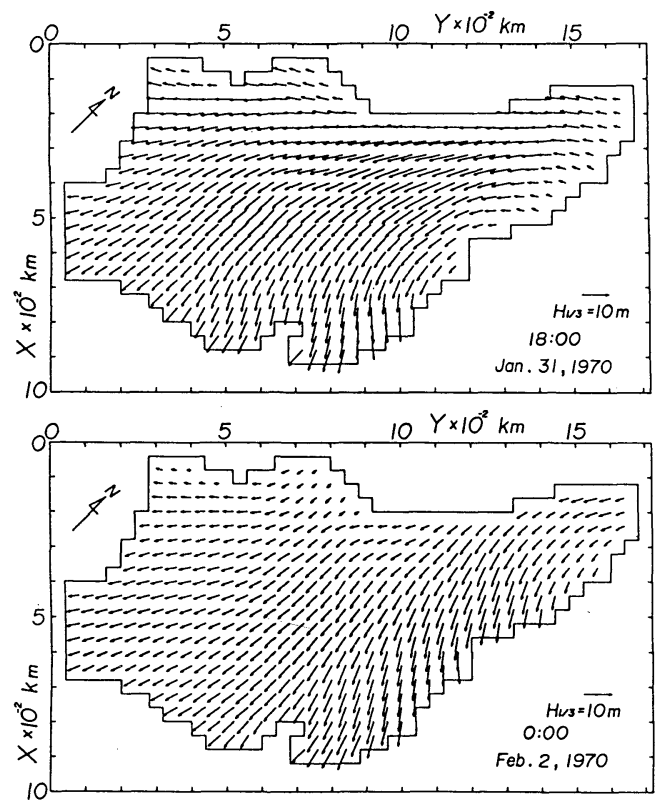

Fig.5 Spatial distribution of significant wave height vector in the Japan Sea.

を福井港および金沢港について示したものである．この 2 地点は相互に近い位置にあるため, 観測結果および追 算結果とも似た経時変化を示すし，いずれの地点におい ても観測結果は浅海性の影響を考慮した計算結果によっ てよく再現されている.

Fig. 5 は低気压の最盛期と減衰期における波高ベクト ルの平面分布を, Fig. 3 と同時刻について示したもので あり，矢印の長さが有義波高を，また矢印の方向が平均 波向を表わす。これらの図によれば，いずれの時刻にお いても日本海北部における風向の空間変化に対応して波 向も反時計方向の変化を示す一方, 中部から西部にかけ ての大部分の海域では $\mathrm{N}$ 方向の波浪が卓越する. そし 
て, 時間の経過とともに反時計方向の波向変化を示す海 域も東に移動し, 領域全体で波向がやや $\mathrm{N}$ 方向に変化 するとともに, 低気圧中心から遠い日本海西部から波高 が減少し始めている，また，海上風分布図によれば，風 向 NW の風が卓越するのに対して, 波高分布図では $\mathrm{N}$ 方向の波浪が卓越することから，日本海西部においては 風向と波向の相違が大きいことがわかる.

\section{4. 北陸海岸における波浪追算}

\section{（1）計算方法}

北陸海岸での波浪追算に用いた格子網は, Fig. 6 に示 すように，能登半島と秋田を結ぶ線以南の小領域を格子 間隔 $\Delta s=10 \mathrm{~km}$ で $11 \times 43$ に分割したものであり，外 海との境界を除く周囲の境界はすべて陸地である．計算 に用いられた周波数および方向は外海での計算ケースと 同様であるが，格子間隔が $1 / 4$ であるので，計算時間間

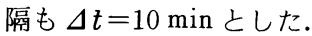

数値計算では, 大領域で計算された能登半島一秋田間 での方向スペクトル（Fig. 6 の黒丸印地点）に，空間お よび時間に関する内挿結果を与えて，対象領域における 波浪を計算した。ただし，この開境界が流出境界になる 場合 $\left(90^{\circ}<\theta<270^{\circ}\right)$ には，方向スペクトルの計算值が

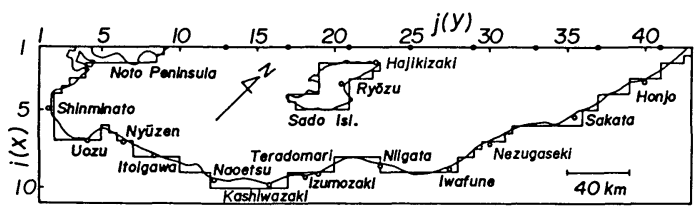

Fig. 6 Grid system (fine mesh).

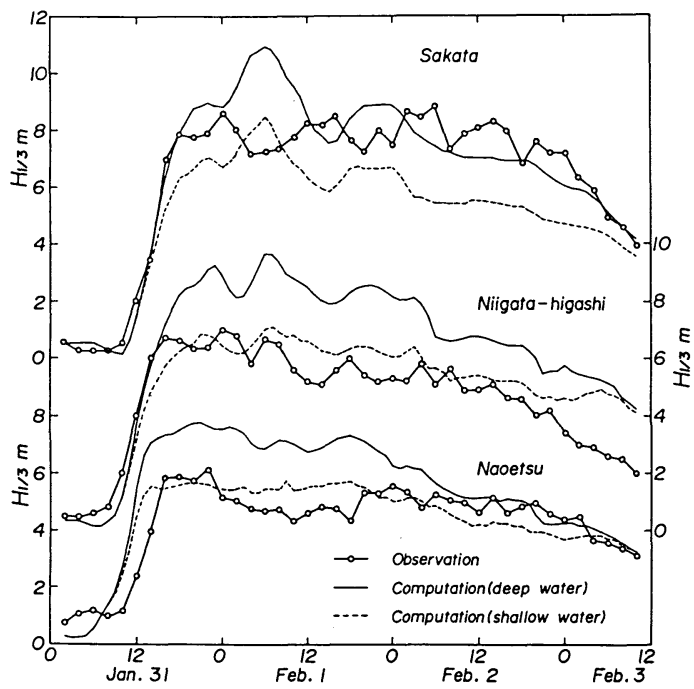

Fig. 7 Comparison between the computed significant wave height and the observed one ( 2 ).
完全吸収されるという流出境界処理を行った.

Fig. 7 は小領域における有義波高の追算結果と観測結 果との比較を酒田港, 新潟東港および直江津港について 示したものであり，計算結果は深海平衡周波数スペクト ルおよび浅海平衡周波数スペクトルを用いた 2 種類の結 果について示されている．まず，酒田港における観測波 高は，発達期では浅海平衡周波数スペクトルを用いた追 算結果により比較的よく再現されているものの，減衰期 では深海平衡周波数スペクトルを用いた結果に近くなっ ている.これに対して，新潟東港および直江津港での波 高はいずれも浅海性を考慮した追算結果によってよく再 現されている。したがって，前述した大領域での対态関 係を含めて総合的に考察すれば，浅海平衡周波数スペク トルを用いた計算結果が深海平衡周波数スペクトルを用 いた場合より相対的に良好な対応を与えると考えられ る.

次に, Fig. 8 は低気圧の最盛期および減衰期における 海上風の平面分布を示したものであり，最盛期では，風 向が領域の西側ほど $\mathrm{NW}$ から $\mathrm{N}$ 方向に，また，岸側ほ દ゙ $\mathrm{N}$ 方向に変化するが，風速は全領域でかなり大きい し，減衰期では，領域の東側で最盛期より風向が $\mathrm{N}$ 寄 りになり，風速も西側ほど減少している，ついで，波高 の平面分布を示した Fig. 9 によれば，いずれの時刻にお

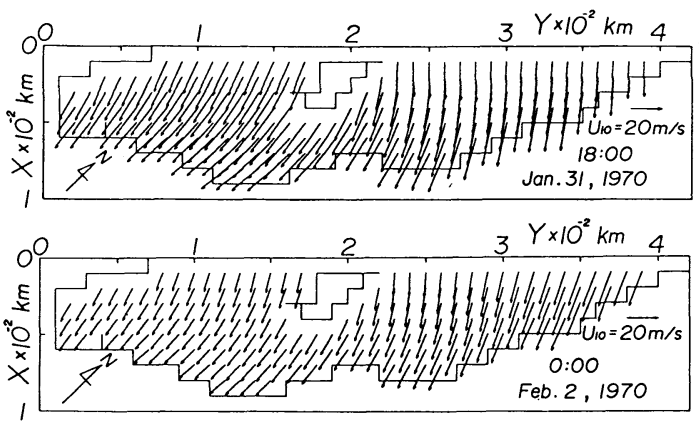

Fig. 8 Spatial distribution of wind vector over the Hokuriku Coast.
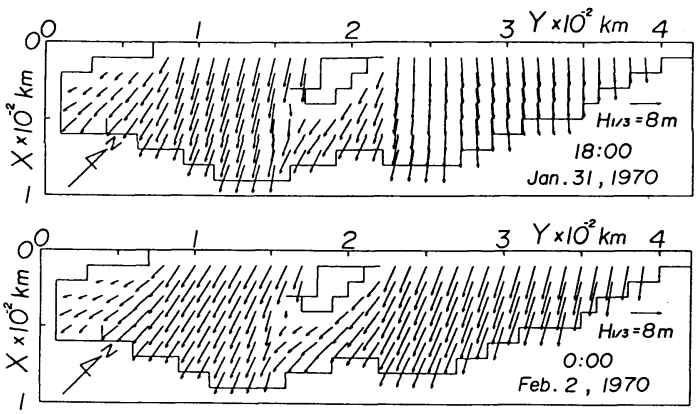

Fig. 9 Spatial distribution of significant wave height off the Hokuriku Coast. 
いても入善〜柏崎および新潟〜秋田間では外洋の波浪が ほとんどそのまま入射するのに対し，入善以西および柏 崎〜新潟間ではそれぞれ能登半島および佐渡島の遮蔽効 果によって波高が減少しているし，また時間の経過とと もに風向が $\mathrm{NW}$ から $\mathrm{N}$ 寄りに変化しているため, 佐渡 島の遮蔽領域もやや西寄りに移動していることが見出さ れる.

\section{5. 佐渡島の波浪遮蔽効果}

\section{（1）－様風時の遮蔽効果}

ここでは佐渡島の遮蔽効果を, 風向 $\mathrm{N}$ あるいは $\mathrm{NW}$ をもつ風速 $20 \mathrm{~m} / \mathrm{s} の 一$ 样風が連吹した場合の計算結果 に基づき考察する．計算条件は，方向分割数が風向に対 して順風となる半平面（風向 $\mathrm{N}$ に対して $-135^{\circ} \sim 45^{\circ}$ お

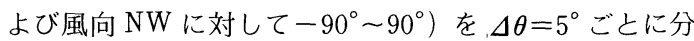
割した 37 個であることを除けば季節風時の場合と同じ である．また，波浪追算も同様に大領域および小領域の 2 段階で砝波項を深海平衡周波数スペクトルに基づき評 価する方法によって実施した。

Fig. 10 は，前述の一様風が 36 時間吹送した時点での 北陸海岸に沿う有義波高分布を，佐渡島が存在する場合 および存在しない場合について海岸から 1 メッシュ沖合 の計算結果から図示したものである，さて，まず風向 NW の場合, 佐渡島が存在しない場合の沿岸波高は, 能登半島の遮蔽効果を受けた領域を除けばほぼ一定であ るのに対して, 風向 $\mathrm{N}$ の場合には東側ほぼ減少する傾 向を示す．これは，岩船から北に向かうにつれて $\mathrm{N}$ か らE 方向の成分波が日本本土によってしだいに遮蔽さ れ始めるためである。，一方，佐渡島の有無による波高分 布の相違，すなわち佐渡島による波浪遮蔽効果は，風向 $\mathrm{N}$ の場合には糸魚川〜寺泊間に，風向 NW の場合には 出雲崎～新潟間に現われることから, 波向により遮蔽領 域が移動することが明らかである，そして，波高減少量 の最大值は風向 $\mathrm{N}$ の場合には $3 \mathrm{~m}$ 程度であるが, 風向

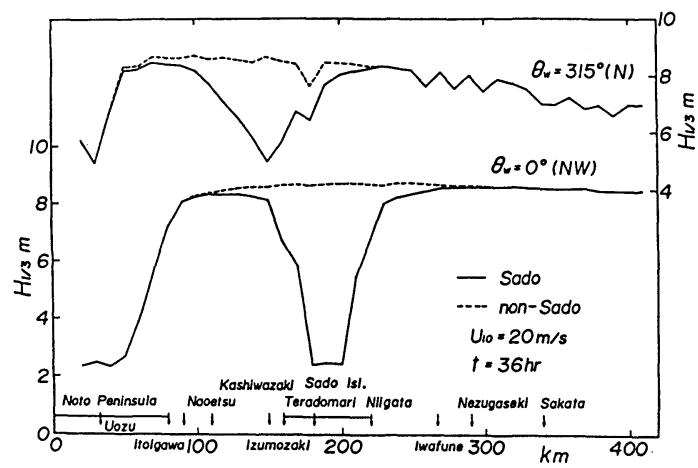

Fig. 10 Sheltering effect of Sado Island on wave height distribution along the Hokuriku Coast ( 1 ).
$\mathrm{NW}$ の場合には $6 \mathrm{~m}$ にも達している。この波高減少量 の相違は, 風向 $\mathrm{N}$ の場合には風向 $\mathrm{NW}$ の場合より佐渡 島の風下側に広い海域が存在するため, 佐渡島で遮蔽さ れた波浪が再び発達することおよび風向 N の場合の佐 渡島の投影長がより短いことによると考えられる。

Fig. 11 は，佐渡島の遮蔽効果が周波数スペクトルに 及ぼす影響を直江津港について示したものである．直江 津港では風向 $\mathrm{N}$ の場合に佐渡島の影響を受け，ピーク 周波数付近および低周波側におけるスペクトルの伝播が 遮断されている，一方，高周波側で遮蔽効果が現われな いのは, 局所風に伴う発達により一定のエネルギーレベ ルが保たれるためである。また，Fig. 12 は直江津港の 方向スペクトルをピーク周波数よりやや低周波側の $0.08 \mathrm{~Hz}$ について示したものである.これから直江津港 では佐渡島の存在により $\mathrm{NE} \sim \mathrm{NNW}$ 方向の成分波の伝 播が遮断されるので，特に $\mathrm{N}$ 方向を主方向とする波浪 成分の減少が大きく, 波向も $W$ 寄りになることがわか

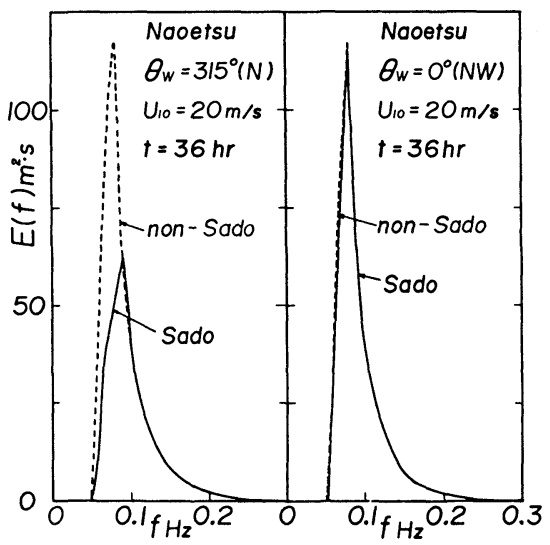

Fig. 11 Sheltering effect of Sado Island on frequency spectrum ( 1 ).

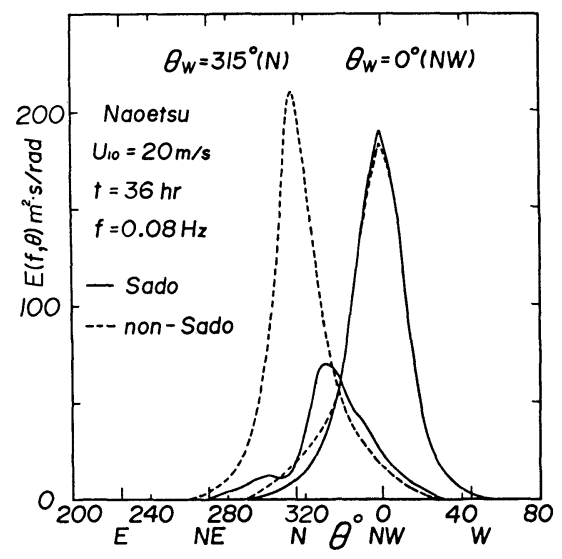

Fig.12 Sheltering effect of Sado Island on directional spectrum ( 1 ). 
る.

\section{（2）季節風時の遮蔽効果}

Fig. 13 は北陸海岸に沿う波高分布を季節風時の 3 時 点について示したものであり，一様風の場合の Fig. 10 に対応している.まず，この季節風時には NW 方向の 風向をもつ海上風が卓越したが，日本海沿岸での風分布 が空間的に変動したため，新潟より東側でも波高分布が 一様風の場合より変化するし, 糸魚川以西での能登半島 による遮蔽領域も時間の経過とともに狭くなっている. また, 佐渡島の遮蔽効果は, 低気圧の最盛期 (31 日 18 時) では直江津〜新潟間に，減衰期（2日０時）では糸魚川 〜新潟間に現われているし，波高が最も減少した地点も 寺泊付近から出雲崎付近に移動している.この間に低気 圧中心は津軽海峡付近から国後島付近に移動しており， 低気圧の移動に伴って遮蔽領域も移動するが，低気圧の 移動速度が遅いためその変化は少ない。 また，最盛期よ り波高がやや減少した時点において，遮蔽効果か顕著に 現われているのはきわめて興味深い.これらの結果を一

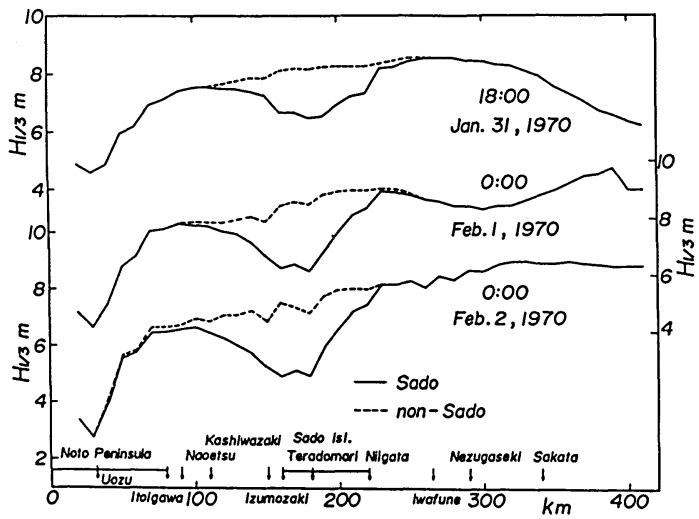

Fig. 13 Sheltering effect of Sado Island on wave height distribution along the Hokuriku Coast (2).

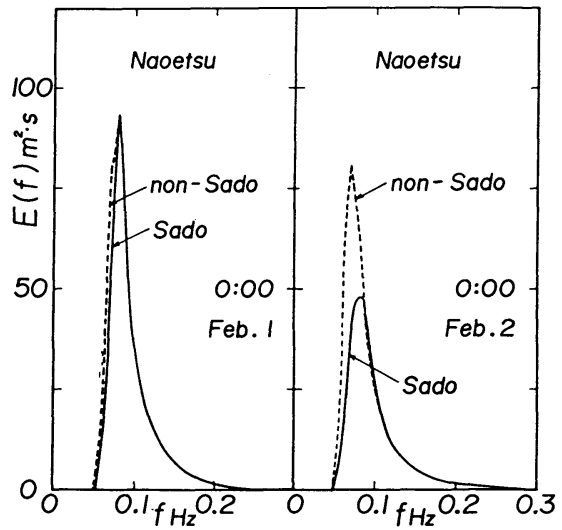

Fig. 14 Sheltering effect of Sado Island on frequency spectrum ( 2).
様風の場合を示した Fig. 10 と比較すれば, 佐渡島の遮 蔽効果が現われる領域は, 風向が $\mathrm{NW}$ から $\mathrm{N}$ 寄りに変 化するに従って $\mathrm{N}$ 方向の一様風が吹送した場合に近づ くけれども，季節風時の波高減少量は一様風の場合より はるかに小さい，これは，実際の季節風時には，風の場 が空間および時間的に変化するので，種々の方向からの 波が当該海域に入射することにより，遮蔽効果がいわば 平滑化されるためであろう.

Fig. 14 および Fig. 15 は，直江津港での周波数スペク トルおよび方向スペクトルを，2 種類の小領域格子網に おける計算結果から図示したものである。これらの図に よれば，佐渡島の有無による計算結果の相違は風向が $\mathrm{N}$ 寄りになった 2 日 0 時に顕著となり，周波数スペク トルにおける遮蔽効果はピーク周波数のやや高周波側か ら低周波側の成分波に対して現われるし，一方，方向ス ペクトルにおける遮蔽効果は NE〜NNW 方向に現われ ている.そして，2 日 0 時での結果は，風向 $\mathrm{N}$ の一様 風が吹送した場合の遮蔽特性に定性的には一致するけれ ども，方向スペクトルに対する遮蔽効果は，波高の場合 に対応して一様風の場合より小さい. また，Fig. 15 に よれば，佐渡島を考慮した場合の方向スペクトルが，そ の存在を無視した場合の方向スペクトルに比べて大きい 波向がある.こうした傾向はFig. 12 に示した一様風の 場合にも見出されるが，特に，Fig. 15 の 2 月 1 日 0 時 において顕著である。これは式（2）に示したように， 砕波に伴うエネルギー減衰を平衡周波数スペクトルに よって評価するという本モデルの特性に起因する，たと えば, 2 月 1 日 0 時の場合，周波数スペクトルの值は佐 渡島の有無にかかわらずほぼ同一であるが，周波数スペ

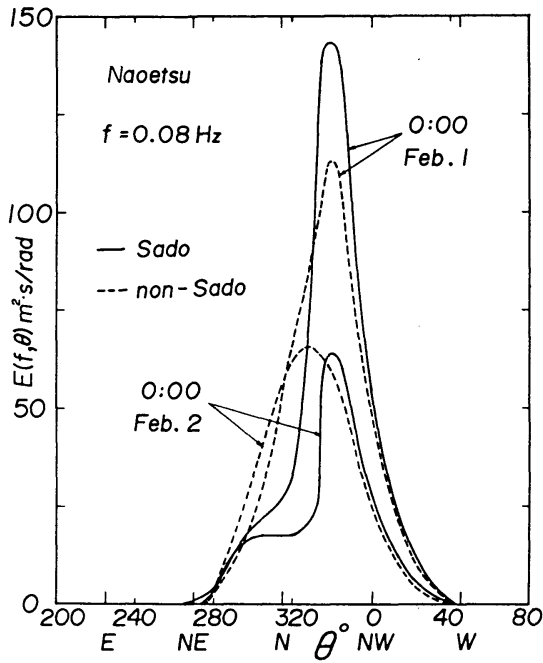

Fig. 15 Sheltering effect of Sado Island on directional spectrum ( 2 ). 
クトルの方向に関する配分率に相当する方向分布関数は 佐渡島の有無によって大いに異なるため, 周波数スペク トルと方向分布関数の積である方向スペクトルも変化 し，前述の結果が得られることになる.

\section{6. 結語}

以上, 本研究では, 著者らが新しく開発したエネルギー 平衡方程式に基づく波浪推算モデルを用いて昭和 45 年 1 月 30 日〜2月 3 日にかけての季節風時における日本 海全体 (大領域) での波浪追算を行うとともに, 能登半 島と秋田を結ぶ線上以南に設けた小領域において，この 計算結果を境界条件として与えた波浪の数值計算を行っ た. 特に, 小領域での計算は佐渡島が存在する場合と存 在しない場合の 2 通りについて行い, 両者の比較から北 陸海岸の波浪分布に及ぼす佐渡島の遮蔽効果を検討し た．その結果，まず，大領域および小領域のいずれにお いても, 浅海平衡スペクトルを用いた計算結果は多くの 場合観測結果とよい一致を示すことから，本研究の波浪 推算法は十分な適用性をもつこと，および設置水深が小 さい波高計で得られた観測結果と計算結果とのよい対応 を特に高波浪時において得るためには浅海性砕波の影響 を考慮する必要があることを見出した．また，数值計算 結果によれば, 日本海全体では風向 NW の強風が卓越 するにもかかわらず，日本海西部海域での波向は，北部 および中央部で発達した波浪が伝播するため $\mathrm{N}$ 方向と なり，風向と異なることがわかった，ついで，小領域に おける計算結果の考察から，一様風が吹送するとき，佐 渡島の遮蔽効果は風向 $\mathrm{N}$ の場合より $\mathrm{NW}$ の場合にはる かに有効に作用して, 遮蔽領域内にあたる寺泊付近では 大きな波高減少が生じるのに対し，現実の季節風時には 風の場が時間的にも空間的にも変化するため, 北陸海岸 での遮蔽領域も移動し, いわば佐渡島の遮蔽効果が平滑 化されるので, 北陸海岸での波高減少量は一様風の場合 ほど大きくないことが明らかになった。

最後に，貴重な風および波資料を提供された運輸省第 一および第三港湾建設局を初めとする関係各官公庁に深 甚の謝意を表明するとともに, 資料の整理や図面の作成 に助力頂いた愛媛大学工学部海洋工学科大福学技官に 感謝する次第である. また, 本研究は文部省科学研究費 自然災害特別研究 (1) (代表: 京都大学 土屋義人教授) による研究成果の一部であることを付記する。なお，本 研究の計算は九州大学大型計算機センターの Facom M-382 および愛媛大学情報処理センターのF Facom
M-180 II AD によった

\section{参 考 文 献}

1）本間 仁・堀川清司・趙 栄燿: 佐渡島の波に対する しゃへい作用, 第 13 回海岸工学講演会講演集, pp. 42 49, 1966.

2）中田邦夫 - 及川 研 - 中尾邦彦・高橋豊喜 - 榎原修治 : 佐渡島の遮蔽効果に関する現地観測, 第 30 回海岸工学講 演会論文集, pp. 179 183，1983.

3）土屋義人：高潮の発生機構とその極值に関する研究， 3.2 波浪の数值予知 $3.2 .2 \mathrm{e}$ 数值予知法の大阪湾への適用性 (山口正隆), 文部省科学研究費自然災害特別研究研究成 果, No. A-56-4, pp. 76 80, 1981.

4）山口正隆 - 畑田佳男 - 日野幹雄 : 台風時における瀬戸内 海西部海域での波浪追算について, 第 21 回自然災害科学 総合シンポジウム講演要旨集, pp. 197〜200, 1984.

5）山口正隆・畑田佳男・大福 学・庄司誠一：スプライン 関数を用いた天気図解析に基づく海上風の推定法につい $\tau$, 第 31 回海岸工学講演会論文集, pp. $128 \sim 132$, 1984.

6）山口正隆 - 畑田佳男 - 日野幹雄 : 波浪推算法に基づく佐 渡島のしゃへい効果の検討, 愛媛大学工学部紀要, 第 10 巻第 4 号, pp. 343 353, 1985.

7) Barnett, T.P. : On the generation, dissipation and prediction of ocean wind waves, Jour. Geophys. Res., Vol. 73, No. 2, pp. 513 529, 1968.

8) Resio, D. T. and Vincent, C. L. : A numerical hindcast model for wave spectra on water bodies with irregular shoreline geometry, Rep.1, H-77-9, Hydraulic Lab., U.S. Army Engineering Waterways Experiment Station, 1977.

9) Isozaki, I. and Uji, T. : Numerical prediction of ocean wind waves, Papers in Meteorol. and Geophys., Vol. 24, No. 2, pp. 207 231, 1973.

10) Hasselmann, K. et al. : Measurements of wind-wave growth and swell decay during the Joint North Sea Wave Project (JONSWAP), Erg. Deutschen Hydr. Zeit., Reihe A, Nr.12, pp.1 95, 1973.

11) Mitsuyasu, H. et al. : Observation of the power spectrum of ocean waves using a cloverleaf buoy, Jour. Phys. Oceanogr., Vol.10, pp. 286 296, 1980.

12）山口正隆・畑田佳男・細野浩司・日野幹雄：エネルギー 平衡方程式に基づく浅海波浪の数値予知モデルについて, 第 31 回海岸工学講演会論文集, pp. 123 127, 1984.

13) Bouws, E. et al. : Similarity of the wind wave spectra in finite depth water, Part I-spectral form-, Jour. Geophys. Res., Vol.90, pp. 975 986, 1985.

14）山口正隆・土屋義人：浅海における波浪の統計的特性の 変形, 愛媛大学紀要, 第 III 部工学, 第 9 巻第 3 号, pp. 299 321, 1980.

(1985.4.22 - 受付) 